\title{
The Influence of Organizational Change (Bank Merger) on Employee's Attitude Response
}

\author{
Achmad Supriyanto \\ Universitas Negeri Malang (UM) \\ Malang-Indonesia \\ aspriess@gmail.com
}

\begin{abstract}
This research aims to examine the influence of organizational change (bank merger) on employee's attitude response. The research design is expost facto. The population involved in the research comprises bank employees working before and after the bank was merged. The population consists of 100 people and the sampling is done in census. Data was taken from respondents through questionnaires and analyzed using PLS 1.8. The findings of the research show that bank merger affects employees' attitude response positively and significantly. If bank merger is judged positively by bank employees, bank merger is able to establish a positive influence for employees' response.
\end{abstract}

Keywords - organizational change, merger, attitude response

\section{INTRODUCTION}

Organizational change (bank merger) is ideally established with good grand design so it can show good performance. Theoretically, "merger between two or more business entities ideally produce business synergy among the merger participants which in their turn they will be able to create continuous value added (sustainable value creation) relying on the improvement of business performance. This business synergy is notated as 1 plus $1>2$, not 1 plus one is $<2$ " (Kiryanto, 2005; Ratnawati and Dewi, 2005).

Bank Merger has several goals: (1) capital structure enforcement; (2) the improvement of deterrence of bank postmerger to the risk and competitiveness of bank post-merger so its positioning in banking world either domestically or internationally is increasingly improved; (3) customer base expansion, so that it generates broader customer segment, the increase of third party fund and the bank ability in distributing credit so that interest income may increase; (4) the expansion of product and service types and variation in banking based on the excellence of each bank; (5) the improvement of sale value so that the government revenue will be optimal; (6) government will receive better revenue than tax and devidend and cash if bank post-merger is divested (Kiryanto, 2005). De Camara \& Renjen (2004) underline that merger activity will last continuously and its integration becomes hot topic for senior excecutives.

The fact shows that organization post-merger does not necessarily describe the expectation. Wikipedia (2005) states that, "historically, though, mergers have often failed to add significantly to shareholder value".
The issue is appointed by Kiryanto (2005). He emphasizes that the idea of merger between banks looks impressively easy to do, but it actually has non-technical thing to be prepared comprehensively so that the merger process will run smoothly.

The condition describes the gap between the expectation and the existing fact. Each employee has unique characteristics, different to each other, and will be brought whenever and wherever. This condition becomes a challenge when they should be integrated into one container of the merger result from several organizations.

The results of preceding studies in relation to merger issue and human resources show that: (1) the change (merger) is responded by manager's employee positively; otherwise, negative attitude is shown by non-manager's employee (Martin, Jones, Callan, 2006); (2) they who participate more to the change for they have higher satisfaction (Alas \& Vadi, 2006); (3) explicitely, merger brings consequency to employe's interest, confusion and agitation (Somers \& Bird, 1990); (4) merger also carries consequence on the employees' stress (Panchal \& Cartwright, 2001); and (4) Human Resource issue (Bryson, 2003).

Based on the study results it can be stated that the interesting issue in relation to the merger and Human Resource attitute proves that the manager's attitude differs from nonmanager's attitude to the merger, which the difference is related to their status. It thoroughly shows that the merger brings negative consequence to non-manager employees; otherwise, merger brings positive consequence to the managers (Somers \& Bird, 1990; Panchal \& Cartwright, 2001).

Merger is a form of radical organizational (Robbins, 1999; Robbins \& Coulter, 1999; McNamara, 2004). Merger aims to sinergize organization members who perform merger, and make them strong, able to adapt to the change or global power (Wibowo, 2003).

Merger from historical perspective has occured since 1960. Merger increasingly improves, that the average takes place 170 times per year between 1960 to 1979 , at average the merger occures 498 times between 1980 to 1989 , and the merger at avergae takes place 514 times per year between 1990 to 1998 (Frohlich \& Kavan, 2006) and still occur up tp now, including in Indonesia (Wikipedia, 2005).

Theoretically, the merger motivation is seen from change theory can be classified into two parts, which are due to 
external dan internal power of organization (Arnold \& Fieldman, 1984; Goodstein \& Burke, 1991; Stoner, Freeman, Gilbert Jr., 1996; Robbins \& Coulter, 1999; and McNamara, 2004). Merger has motives on the improvement of net present value (Pringle \& Harris in Samosir, 2003); and global factor (Samosir, 2003). The results of study conduced by Sunarsip (2005) shows that there are several antecedent mergers (the result is failed), which are financial compatibility, product, consumers, geographical reach, cost-cutting/efficiency synergies, and leader vaccum. The result of the study shows that the merger may be successful for there is simple communication, good company culture, positive change, controlled stress, and good strategy (Appelbaum, Gandell, Shapiro, Belisle, \& Hoeven, 2000), bargaining power (Palmer, Parry, \& Webb, 2005) and human resource ability (Lin, Hung, $\& \mathrm{Li}, 2006)$. The sresult of the study conducted by Frohlich \& Kavan (2006) shows that bank motives to do merger is for economic scale creation and improvement, expansion of geografical areas, capital size improvement, and product opening, and market achievement/domination.

Bank merger can be seen from two things, merger process aspect and merger result. Merger process has three main stages, which are preparation (unfreezing), implementation (changing), evaluation (refreezing) as being explained (Arnold \& Fieldman1986; Robbins \& Coulter, 1999; Clarke, 1999; CMLC, 2004). As the follow-up of the merger process will be produced a number of changes. The change taking place is not only on organization integration, but also on structural, technological, physical setting, human and organization culture aspects (Robbins, 1996; Sttoner, Freeman, Gilbert Jr., 1996; Robbins and Coulter, 1999). The result of the study conducted by Appelbaum, Gandell, Shapiro, Belisle and Hoeven (2000) shows that the merger process is done through three steps, which are pre-merger, during merger, and post-merger.

Merger as the form of radical organizational change is certainly a stimulus for the members (employees) of the organization. The interaction between the organization and the members becomes integral part in organizational life. Each stimulus in organization will be responded by the members. Bank merger as the stimulus is responded by the employees (Robbins, 1996; Stoner, Freeman \& Gilbert Jr., 1996; Arnold \& Fieldman, 1986; \& Luthans, 1998).

The employyes' response to the existing stimulus can be the response of constructive attitude and destructive response. Both attitudes contain three main components, which are affection, cognition and behavior (Rosenberg, 1960; Breckler, 1984). Constructive attitude can be used as positive predictor of the members to the organization. Otherwise, destructive attitude can be employed as negative predictor of the members to the organization (Gibson, Ivancevich, \& Donnelly, 1984; Rusbult \& Lowery, 1985; Robbins \& Coulter, 1999; Clarke, 1999; Newstrom \& Davis, 2002).

The result of the study performed by Sverke, Chaison, \& Sjoberg (2004) shows that the merger can affect psychological effect such as attitude and the behavior of organization members. The merger can be directed to the level of commitment and participation of the members in performing activities. The result of the study conducted by Somers and
Bird (1990) states that the merger process affects negatively to the employee's attitude (interest, confusion, agitation). The result of the study conducted by Panchal \& Cartwright (2001) shows that pre-merger affects the employee's stress and negative attitude. Martin, El Jones \& Callan (2006) suggest the result of their study that the merger affects high-level employee attitude (Manager) significantly and positively. The results of the study show that the merger affects the respose of employee's attitude with the classification are either positive or negative.

This study aims at finding the influence of organizational change (bank merger) to the employee's attitude response.

\section{METHOD}

This study employs ex-post facto design. The study employs the the past events (Gunadharma, 2004; Watson, 2006), and the data is collected after all problematic events taking place (Suryabrata, 2005).

This study resides in merger-generated banks, which are (1) Bank Mandiri Malang Branch (Jl. Wahid Hasyim Malang); (2) Bank Permata Malang Branch (Jl. Bromo Malang); and (3) Bank Danamon Malang Branch (Jl. Kawi Malang). The reasons are: (1) it gains interest from many people and being the pioneer of merger-performing banking; (2) executing organizational change program radically; (3) it is projected to be anchor bank in the future; (4) it can be used as other bank model or organization performing merger in the future; (5) as an open organization.

The target population of this study consists of the employees (manager and non-manager) working (before and after the bank performs merger) in Malang.

The population of this study is 100 people. The number comprises: (1) 52 employees of Branch Office of Bank Mandiri in Malang; (2) 34 employees of Branch Office of Bank Permata in Malang; and (3) 14 employees of Branch Office of Bank Danamon in Malang.

This study consists of two variables, which are organizational change (bank merger) and attitude response. Organizational change variables (merger) have two dimensions which are the process and the result of change and the response of attitude has two variable dimensions which are constructive attitudes (loyalty, expressing change, and positive response) and destructive attitude (leaving organization, ignoring and responding negatively).

Based on the variable and indicator measured, research instrument is established in form of questionnaires. Relying on the indicator outlined into statement items or questions in the questionnaires.

Validity test and intrument reliability employ SEM Alternative Method Partial Least Square or PLS 1.8 and SPSS 12.00 (Gozali, 2006 and Computer, 2004). The result of test is required and intended to step into model testing. The validity test employs convergent validity and discriminant validity. The validity test is stated good if the loading value is above 0.5 (Gozali, 2006). The reliability test employs composite reliability analysis. The analysis of composite reliability can be 
seen by square root of average variance extracted (AVE) for each construct to other constructs in the model.

If the root of Average Variance Extracted (AVE) of each construct is greater than the correlation between the construct and other constructs means the model has good composite reliability (Ghozali, 2006).

In accordance with the target of research population and sample, data collection which the questionnaires have been prepared and delivered to the respondents. The number is 100 exemplars, but only 60 exemplars return. The reasons are: (1) there are six (6) questionnaires do not return; and (2) there are 34 respondents are not allowed to fill the questionnaires by management.

The research data is analyzed by PLS 1.8 program $(\mathrm{Li}$, 1987). This instrument is employed to integrated analysis between data analysis and concept construction. Through this analysis, the result obtained consists of: (1) validity and instrument examination (equal to confirmatory analysis factor), (2) model testing of the relation between latent variable (equal to path analysis), and (3) the model is advantageous for estimation (equal to regression analysis) (Ferdinand, 2006; Solimun, 2001; Gozali, 2006).

\section{RESULT}

Based on the analysis result it is identified that path coefficient of organizational change influence (bank merger) to the attitute response (constructive) has path coefficient value of 0,692 ;

Path coefficient produced needs testing or further testing to know the level of significance. Based on the result of analysis to significance test to path coefficient, error, and t-value can be stated (1) organizational change (bank merger) influences the attitude response (constructive) positively and signicantly with path coefficient value 0,692 , the error level of 0,07 , and t-value of 9,868 .

\section{DISCUSSION}

Bank merger influences the attitude response (constructive) of the employees positively and significantly can be discussed as follows. The result of research supports the findings: (1) Sverke, Chaison, \& Sjoberg (2004) proving that the merger can affect psychological effect such as attitude and behavior of organization members (they do not show whether it is constructive or destructive attitude); and (2) Martin, Jones \& Callan (2006) who have proved that an organizational change affects the manager positively and significantly.

The result of the study also supports the study which has proved that bank merger as the form of radical organization change is a stimulus for the members (the employees) of organization. The interaction between the organization and the members become integral part. Each stimulus from organization will be responded by the members. The stimulus derived from organizational change for doing the merger is responded by the members (Robbins, 1996; Stoner, Freeman and Gilbert Jr., 1996; Arnold \& Fieldman, 1986; \& Luthans, 1998).
The result of the study does not completely support the preceding study, for Martin, Jones \& Callan (2006) show that for non-manager employee group, big change (merger) is proven to influence negatively on them. The concern is although the manager's attitude is positive and the feeling is more controllable, but they feel obtain greater stress than those who work as manager (Martin, Jones \& Callan, 2006). The managers' attitude shows inconsistency between constructive attitude and destructive attitude. The researcher assumes that the stress is more as a challenge as the consequence of the big change. The response of positive attitude of the employee of bank merger can be used as the reference of positive predictor in establishing organization in the future (Gibson, Ivancevich, \& Donnelly, 1984; Rusbult dan Lowery, 1985; Robbins \& Coulter, 1999; Clarke, 1999; and Newstrom \& Davis, 2002).

The finding of the study proves that the organizational change (bank merger) influences the attitude response (constructive) of the employee of bank merger (sequenced from the indicator obtaining the highest score mean): (1) discussing and accomplishing issue (3,77); (2) giving suggestion for improvement $(3,70)$; (3) trusting the management performs proper action $(3,67)$; (4) defending institution from outside critics $(3,52)$; (5) expressing through labor union $(3,50)$; (6) trusting organization performs proper action $(3,45)$.

Construction attitude response shown by the employees to bank merger, particularly to express the expectation through discussion and the settlement of each issue encountered and shows loyalty to organization by trusting leader to perform the most proper action in undertaking the programs of bank merger (Rusbult \& Lowery, 1985).

The attitude's response (constructive) shown by the employees of bank merger actually cannot be separated by their own characteristics. They have adequate job experience (on the average working before and after merger for more than 15 years, the level of bachelor education, salary, and allowance ranging from satisfying to satisfying enough.

The reason is enforced by the attitude response of the employees who less agree on destructive things. The destructive attitude responses which gain less approvals from the employees (starts from the smallest mean score), which are (1) skiping work $(1,45)$; (2) effort for improvement is reduced (1,53); (3) coming too late/chronically late $(1,73)$; making errors at work more serious $(1,73)$; feeling scared, anxious, startled, and losing confidence $(1,77)$; losing motivation $(1,83)$; losing self-esteem $(1,85)$; feeling angry, stressed and confused $(1,90)$; leaving the past issue $(1,98)$; establishing organizational politics $(1,43)$; critical reactions $(3,40)$.

The result of this study means that the destructive attitude response shown by the employees only on the approval of critical reactions (negative reaction), whereas the thing which is not approved is the attempt to skip work (ignorance to the organization). This condition is the proof that although they encounter radical change, the employees do not really agree on destructive attitude. This is inseparable from their characteristics which have adequate job experience, the level of education is dominated by bachelors, salary and allowance range from satisfying to satisfying enough. The researcher 
assumes, regarding their position in bank merger is relatively safe, than it is not likely to show destructive attitude response.

The checking result to the field through interview with several employees show that although bank merger is radical, they still show constructive attitude response. Several main reasons are for to the employees: (1) feel safe to work at the bank regarding the situation at the time is in sustainable critical condition; (2) have ability only in banking (according to the position); and (3) they have to look for other job.

Concerning the results and limitations found in this study, then it can be stated the advanced research implication as follows. First, advanced study can be conducted with review not limited to those who are still working at banks which the merger the respondents, but it can also includes ex-bank officers who do not work at bank merger. This becomes so strategical if it will be able to reveal their behavior before and after the bank performs merger, including how their strategy in overcoming the issue of organizational change and should make decision or leave the bank. Consequently, the researcher shoud be able to trace the existence of ex bank performing merger. The more proper research design for this advanced study is qualitative design. Through qualitative design, we will find new meanings or new prepositions which are very advantegous for stuy enrichment about bank merger and various implication to the employees in the future. Second, the advanced study can be expanded not only in bank merger institution, but also in other institutions or organizations which are performing, and have performed merger. If this advanced study can be performed then it will enrich the results of the preceding study, aprticularly in relation to organization merger and it influences each existing component, and the performance is seen from non-financial aspect. Third, other advanded study needs to concern time aspect. If the study on organizational change by using expost facto design is better, it is performed soon after the change, particularly in answering whether self-adaptation affects organization employee's performance performing merger.

\section{CONCLUSION}

Organizational change (bank merger) is proven affecting the employee's attitude response positively and significantly. The employee's attitude response to bank merger is constructive. That is to say, the better the employee's evaluation on bank merger, it may create constructive attitude response of bank merger employees. Bank merger is considered good by the employees working before and after merger. Based on the evaluation, they respond to bank merger constructively.

\section{RECOMMENDATION}

Government in making decision of merger should: (1) be focussed on comprehensive planning, product improvement of those broadly accepted, and synergy between all components optimally; (2) observe more comprehensively not only from financial aspect but also non-financial aspect, particularly nontechnical aspect from human resources; (3) require the readiness between various components of merger-prospective banking institution.

\section{REFERENCES}

[1] Alas, R. dan Vadi, M. 2006.The employees' attitudes and their connections with the organisational culture in the process of change in the Estonian organizations. Baltic Journal of Management. ISSN: 1746-5265. Volume: 1 Issue: 1 p: 49-66.

[2] Appelbaum, S.H.; Gandell, J.; Shapiro, B.T; Belisle, P.; dan Hoeven, E. 2000. Anatomy of a merger: behavior of organizational factors and processes throughout the pre- during- post- stages part 2. Management Decision. ISSN: 0025-1747. Volume: 38 Issue: 10 p: 674-684

[3] Arnold, H.J. \& Feldman, D.C. 1984. Organizational Behavior. Singapore: McGraw-Hill, Inc.

[4] Breckler, S.J. 1984. Empirical Validation of Affect, Behavior, and Cognition as Distinct Component of Attitude. Journal of Personality and Social Psychology, p 1191-1205.

[5] Bryson, J. 2003.Managing HRM risk in a merger. Employee Relations. ISSN: 0142-5455. Year: Feb 2003 Volume: 25 Issue: 1 p: 14-30.

[6] Clarke, L. 1999. The Essence of Change Memanajemen Perubahan. Diterjemahkan Muslie, M. dan Soenarjo, M.. Yogyakarta: Andi dan Simon dan Schuster Asia Pte. Ltd.

[7] De Camara, D. dan Renjen, P. 2004. The Secret of Succesful Mergers: Dispatches from the front lines, Journal of Business Strategy JST, ISSN: 0275-6668, Vol: 25 Iss:3 Date:2004 p:10.

[8] Ferdinand, A. 2006. Metode Penelitian Manajemen. Pedoman Penelitian untuk Penulisan Skripsi, Tesis dan Disertasi Ilmu Manajemen. Semarang: Badan Penerbit Universitas Diponegoro.

[9] Frohlich, C. \& Kavan, C.B. 2006. An Examination of Bank merger Activity: A $\quad$ Strategic
Analysis. http://www.unf.edu/ cfrohlic/ metings lmergers.ppt

[10] Gibson, J.L., Ivancevich, J.M. dan Donnelly Jr, J.H. 1984. Organisasi dan Manajemen: Perilaku, Struktur, dan Proses. Edisi keempat. Alih Bahasa: Wahid, Dj. Jakarta: Erlangga.

[11] Goodstein, L.D. \& Burke, W.W. 1991. Creating Successful Organization Change. Organizational Dynamics. Amarican Management Association International. http://www.amanet.org.

[12] Gunadharma. 2004. Metode Penelitian Ex Post Facto. http://library.gunadarma. ac.id/files/ disk1/14/jbptgunadarma-gdlcourse-2004-irapuspita-695-eksperim-1.ppt.

[13] Kiryanto, R. 2005. Desakan Merger Perbankan Semakin Krusial. Pikiran Rakyat http://wWW.pikiran rakyat.com/cetak/2002.html.

[14] Lin, B.W.; Hung, S.C.; Li, P.C. 2006. Mergers and acquisitions as a human resource strategy: Evidence from US banking firms, International Journal of Manpower. ISSN: 0143-7720. Volume: 27 Issue: 2 p: $126-142$

[15] Luthans. F. 1998. Organizational Behavior. New York: McGraw-Hill.

[16] Martin, A.J.; Jones, E.S. Callan, V.J. 2006 Status differences in employee adjustment during organizational change. Journal of Managerial Psychology. ISSN: 0268-3946. Volume: 21 Issue: 2 p: 145-162.

[17] McNamara, C. 2004. Basic Concep of Organizational Change. The Management Assistance Program for Nonprofits. 2233 University Avenue West, Suite 360.St. Paul, Minnesota 55114. http://www.managemenhelp. org/topic. htm. April, $28,2007$.

[18] Newstrom, J.W. dan Davis, K. 2002. Organizational Behavior: Human Behavior at Work. International Edition. United States: McGraw-Hill Company.

[19] Palmer, J.; Parry, J,; Webb, M. 2005. Small unions and mergers: evidence from two case studies, Employee Relations, ISSN: 0142-5455, Volume: 27 Issue: 4 p: 340-353,

[20] Panchal, S. dan Cartwright, S. 2001. Group differences in post-merger stress. Journal of Managerial Psychology. ISSN: 0268-3946., Volume: 16 Issue: 6 p: 424-433.

[21] Ratnawati, R. dan. Dewi, Y.S. 2005. Konsolidasi Perbankan Nasional. Economic Review Journal. No. 199, Mar 2005 , 
http://www.bni. co.id/Document/ 17\%20 konsolidasi. pdf, html. February, 20, 2007.

[22] Robbins, S. 1996. Perilaku Organisasi: Konsep, Kontroversi, Aplikasi. Edisi Kedua. Alih Bahasa: Pudjaatmaka, H. Jakarta: Prenhallindo.

[23] Robbins, S. P.; Coulter, M. 1999. Manajemen II. Jakarta: Prenhallindo.

[24] Rosenberg, M.J. 1960. A Structural Theory of Attitudes. Public Opinion Quarterly. p: 319-340.

[25] Rusbult, C. \& Lowery, D. 1985. When Bureaucrats Get the Blues. Journal of Apllied Social Psychology, Vol. 15. No. 1 p:15.

[26] Samosir, A.P. 2003. Analisis Kinerja Bank Mandiri Setelah Merger dan Sebagai Bank Reekapitalisasi. Kajian Ekonomi dan Keuangan. Vol 7 , No. 1. Maret 2003.

[27] Solimun. 2001. Structural Equation Modelling SEM dan Lisrell. Malang: Program Pascasarjana Universitas Brawijaya Malang.

[28] Somers, M.J. dan Bird, K. 1990. Managing the Transition Phase of Mergers. Journal of Managerial Psychology. ISSN: 0268-3946. Volume: 5 Issue: 4.

[29] Stoner, J.A.F.; Freeman, R.E.; Gilbert Jr, D.R. 1996. Manajemen II. Jakarta: Prenhallindo.
[30] Sunarsip 2005. Mencegah Kegagalan Merger Perbankan. (online), http://www.bisnis. page? pageid=487 dan dad= portal30dan_schema $=P O R T A L 30$ dan_mode $=3$ danvnw lang $i d=2$ danptopik=A15dañcdate $=04$ -DEC-2001daninw_id=169401). Accesed 10 Agustus 2015

[31] Suryabrata, S. 2005. Metodologi Penelitian. Jakarta: Raja Grafindo Persada.

[32] Sverke, M; Chaison, G.N.; and Sjoberg, A. 2004. Do Union Mergers Affect the Members? Short-and Long-term Effects on Attitudes and Behavior. Economic dan Industrial Democracy EID ISSN: 0143-831X, Vol: 25 Iss: 1 Date: Feb 2004 p:103.

[33] Watson, J. 2006. The Experimental Designs. http://encourse.amberton.edu/grad /RG 56035E1/ASSIGN4.htm. June, 11, 2006.

[34] Wibowo, S. 2003. Merger BUMN: Wacana Ambisius yang Sulit Diwujudkan, Sinar Harapan.

[35] Wikipedia. 2005. Mergers and Acquisitions. Wikimedia Foundation. Inc. (Online), (hțtp://en.wikipedia. org/wiki/ Mergers_and acqui sitions),_Accesed on August, 18, 2007. 